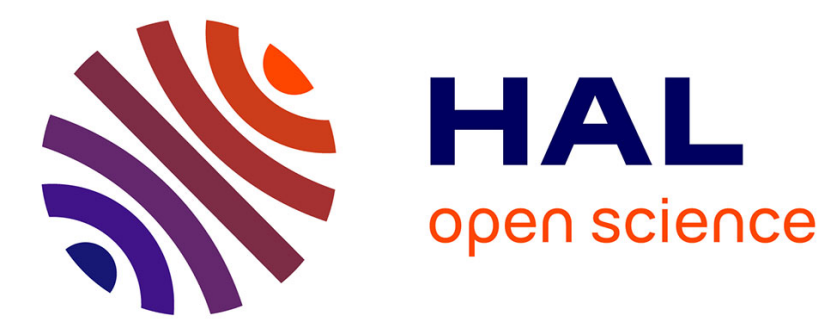

\title{
On the Origin of Ultramylonites
}

Jacques Précigout

\section{To cite this version:}

Jacques Précigout. On the Origin of Ultramylonites. EGU General Assembly 2020, May 2020, Online, France. 10.5194/egusphere-egu2020-3938 . hal-03554442

\section{HAL Id: hal-03554442 \\ https://hal.science/hal-03554442}

Submitted on 3 Feb 2022

HAL is a multi-disciplinary open access archive for the deposit and dissemination of scientific research documents, whether they are published or not. The documents may come from teaching and research institutions in France or abroad, or from public or private research centers.
L'archive ouverte pluridisciplinaire HAL, est destinée au dépôt et à la diffusion de documents scientifiques de niveau recherche, publiés ou non, émanant des établissements d'enseignement et de recherche français ou étrangers, des laboratoires publics ou privés. 
EGU2020-3938, updated on 03 Feb 2022

https://doi.org/10.5194/egusphere-egu2020-3938

EGU General Assembly 2020

(c) Author(s) 2022. This work is distributed under

the Creative Commons Attribution 4.0 License.

\section{On the Origin of Ultramylonites}

\section{Jacques Précigout}

Earth Sciences Institute (ISTO), University of Orléans, CNRS-BRGM, UMR7327, Orléans, France (jacques.precigout@univorleans.fr)

Deformation of lithospheric rocks regularly localizes into high-strain shear zones that include finegrained ultramylonites. Occurring as quasi-straight layers of intimately mixed phases that often describe sharp transitions with the host rock, these structures may channelize fluid flow ${ }^{[1,2]}$ and could serve as precursors for deep earthquakes ${ }^{[3]}$. However, although intensively documented, ultramylonites originate from still unknown processes. Here I focus on a mylonitic complex that includes numerous mantle ultramylonites in the Ronda peridotite (Spain). Among them, I was able to highlight one of their precursors that I better describe as a long and straight grain boundary, along which four-grain junctions are observed with randomly oriented grains of olivine and pyroxenes. This precursor starts from a pyroxene porphyroclast and extends to an incipient, weakly undulated ultramylonite, where intimate phase mixing arises with asymmetrical grain size distribution. While the finer grain size locates on one side, describing a sharp - but continuous transition with the host rock, the grain size gradually increases towards the other side, giving rise to a smooth transition. All phases have a very weak lattice preferred orientation (LPO) in the ultramylonite, which strongly differs from the host rock where olivine is highly deformed with evidence of high dislocation densities and a strong LPO. Altogether, these features shed light on the origin of mantle ultramylonites that I attribute to a migrating grain boundary, the sliding of which continuously produces new grains by phase nucleation, probably at the favor of transient four-grain junctions. Nucleated grains then grow and progressively detach from the precursor as it keeps on migrating depending on the dislocation densities in the host rock. Although such an unusual grain boundary remains to be understood in terms of source mechanism, these findings provide new constraints on the appearing and development of ultramylonites.

[1] Fusseis, F., Regenauer-Lieb, K., Liu, J., Hough, R. M. \& De Carlo, F. Creep cavitation can establish a dynamic granular fluid pump in ductile shear zones. Nature 459: 974-977 (2009)

[2] Précigout, J., Prigent, C., Palasse, L. \& Pochon, A. Water pumping in mantle shear zones. Nat. commun. 8: 15736, https://doi.org/10.1038/ncomms15736 (2017)

[3] White, J. C. Paradoxical pseudotachylyte - Fault melt outside the seismogenic zone. J. Struct. Geol. 38: 11-20 (2012) 